TURJE

www.turje.org

\title{
Teachers' knowledge about autism spectrum disorder: The case of Turkey
}

\author{
Salih Rakap \\ Ondokuz Mayis University, Faculty of Education, Samsun, Turkey, srakaptr@gmail.com \\ orcid.org/0000-0001-7853-3825 \\ Şerife Balıkcı \\ Dumlupınar Primary School, Samsun, Turkey, seriferakap@gmail.com \\ orcid.org/0000-0003-3740-8037 \\ Sinan Kalkan \\ Ondokuz Mayis University, Faculty of Education, Samsun, Turkey, sinan.kalkan@omu.edu.tr \\ orcid.org/ 0000-0002-6731-8406
}

\begin{abstract}
Teachers' knowledge and perceptions about autism spectrum disorder (ASD) is found to be a critical component for the identification and education of children with ASD. This study examined Turkish general education teachers' knowledge and perceptions about ASD. A total of 478 general education teachers across four school types participated in the study. Data were collected using an online survey package. Results showed Turkish general education teachers across all school types and grade levels had limited knowledge and perceptions of autism. Findings show that there is an urgent need to develop professional development or certification programs to train teachers to work with children with ASD. Implications for future research and practice are discussed.
\end{abstract}

Keywords Autism, General education teachers, Knowledge, Perception, Treatment,

\section{Öğretmenlerin otizm spektrum bozukluğu hakkında bilgileri: Türkiye örneği}

ÖZ Öğretmenlerin otizm spektrum bozukluğu (OSB) hakkındaki bilgi ve algıları bu çocukların tanılanmaları ve eğitimleri için kritik öneme sahiptir. Bu çalışmada, anaokulu, ilkokul, ortaokul ve lise kademelerinde görev yapan öğretmenlerin OSB hakkındaki bilgi ve algıları incelenmiştir. Çalışmaya bu dört eğitim kademesinde görev yapan 478 genel eğitim öğretmeni katılmıştır. Çalışmanın sonuçları farklı eğitim düzeyinde görev yapan öğretmenlerin OSB hakkında sınırlı bilgiye sahip olduklarını ve öğretmenlerin bilgi düzeylerinin çalıştıkları eğitim kademelerine göre farklılık gösterdiğini ortaya koymuştur. Bulgular, OSBli çocuklara çalışan ve çalışma olasılığı olan öğretmenler için acil bir şekilde mesleki gelişim programlarının geliştirilmesi ve uygulanması gerektiğini göstermektedir. Makalenin sonunda gelecekte yapılacak araştırma ve uygulamalar için öneriler sunulmuştur. 


\section{INTRODUCTION}

Autism spectrum disorder (ASD) is a neurodevelopmental disorder characterized by persistent difficulties in social communication and interactions across multiple contexts and restricted, repetitive patterns of behavior, interests, or activities that manifest within the early development period (American Psychiatric Association, 2013). Although exact causes of autism are not known, it is generally accepted that autism occurs as a results of abnormalities in brain structure or function and recent studies have been investigating the link between autism and genetic, environmental factors, and medical problems (Autism Society of America, 2015). Autism can be diagnosed reliably by the age of three based on data and information obtained from multiple resources including psychological, educational, or developmental tests, behavior observations, and interviews with family members and caregivers (Autism Society of America, 2016; Rakap, 2017; Shaw \& Hatton, 2009).

According to the most recent report of the Centers for Disease Control and Prevention (CDC) on the prevalence of ASD, the disorder occurs in approximately 1 in 68 children and boys are five times more likely to have ASD than girls (Baio, 2014). While there is no cure for ASD, early diagnosis is important as the research evidence suggests that interventions designed to improve functioning of individuals with ASD may be more effective in younger children and optimize long-term effects (Arif, Niazy, Hassan, \& Ahmed, 2013; Guthrie, Swineford, Nottke, \& Wetherby, 2013; Koegel, Koegel, Ashbaugh, \& Bradshaw, 2014; Rakap, 2017; Reichow, Hume, Barton, \& Boyd, 2018; Volkmar, Rogers, Paul, \& Pelphrey, 2014). Evidence-based interventions that are effective for improving outcomes for children with autism include behavioral interventions, comprehensive behavioral treatment, language training, social skills training, parent training, naturalistic teaching, peer training, and pivotal response training (National Autism Center [NAC], 2015). Moreover, the NAC (2015) identified a number of intervention approaches with emerging evidence about their effectiveness. These include functional communication training, developmental relationship-based treatment, picture exchange communication system, exercise, imitation-based intervention, massage therapy, music therapy, and sign instruction (NAC, 2015).

There has been a documented increase in the prevalence of ASD around the world (Arif et al., 2013; Elsabbagh et al., 2012; Kim et al., 2011) and Turkey as a country with very young population is not exception to this (Rakap, 2017). Although there is no national surveillance system to estimate the numbers of individuals with autism in Turkey, increasingly more children are being diagnosed with autism in recent years and receive educational and developmental services in schools/classrooms specifically designed for children with autism or in inclusive classrooms under the public school system (Cakiroglu \& Melekoglu, 2014; Rakap, 2017; Rakap, Balikci, Parlak-Rakap, \& Kalkan, 2016). With the escalation in prevalence and increase in the number of children with ASD in public school system, having knowledge of the disorder becomes increasingly important for educators who are likely to work with children with ASD (Koegel \& Koegel, 1995; Lane, Carter, Common, \& Jordan, 2012).

A number of studies have investigated the knowledge in autism of professional from various fields since late 1980s. Stone (1987) who investigated autism knowledge of pediatricians, clinical psychologists, speech/language pathologists, school psychologists, and other specialists in the field conducted one of the first studies and reported that there were misconceptions in all professional groups; however, the specialists had the most current knowledge. Since the Stone (1987) study, surveys have included knowledge, perceptions, and understanding of other healthcare professionals (Hartley-McAndrew, Doody, \& Mertz, 2014; Heidgerken, Geffken, Modi, \& Frakey, 2005; Imran et al., 2011; Ozcelik et al., 2015), speech language pathologists (Cascella \& Colella, 2004; Schwartz \& Drager, 2008), medical students (Shah, 2001), pharmacists (Khanna \& Jariwala, 2012), occupational therapists (James, Pizur-Barnekow, \& Schefkind, 2014), residents of a college campus (Tipton \& Blacher, 2014), pre-service teachers (Hart \& More, 2013; Park, Chitiyo, \& Choi, 2010; Rakap et al., 
2016; Yasar \& Kronin, 2014), and educators (Al-Sharbati et al., 2015, Arif et al., 2013; Helps, Newsom-Davis, \& Callias, 1999; Mavropoulou \& Padeliadu, 2000; Syriopoulou-Delli, Cassimos, Tripsianis, \& Polychronopoulou, 2012; Yumak \& Akgul, 2010). These studies reported mixed findings with respect to professionals' knowledge, perceptions, and understanding of autism.

Of these studies, four were conducted with professionals (not inclusive of teachers) in Turkey (Ozcelik et al., 2015; Rakap et al., 2016; Yasar \& Kronin, 2014; Yumak \& Akgul, 2010). Ozcelik and colleagues (2015) examined knowledge and attitudes of 270 pediatricians and reported that pediatricians did not have through knowledge of Diagnostic and Statistical Manual of Mental Disorders 4 (DSM 4; American Psychiatry Association [APA], 1994) criteria for autism; they were not familiar with comprehensive evaluation techniques used to diagnose children with autism; and they did not feel comfortable giving diagnosis of autism. Yasar and Cronin (2014) investigated knowledge and awareness of autism among 551 pre-service teachers enrolled in 10 different teacher education programs across two universities. Researchers found that pre-service teachers across teacher education programs had inadequate knowledge of autism. Rakap et al. (2016) explored the knowledge in autism of teacher candidates who are likely to have the initial contact with children with autism within public school system in Turkey. Five hundred and four senior pre-service teachers enrolled in four different teacher education programs participated in the study and results indicated that pre-service teachers across programs had limited knowledge of autism including characteristics and diagnosis. Yumak and Akgul (2010) investigated perceptions of autism of 117 elementary school administrators and teachers working in public schools Turkey and found that participants had very limited knowledge of and training in autism, and they did not know how to work with children with autism and therefore could not develop positive attitudes towards children with autism.

This study was designed to examine Turkish teachers' general knowledge and perceptions about autism spectrum disorder, explore their knowledge about evidence-based practices in ASD, and examine their training needs to serve children with ASD. Five primary research questions were addressed: First, what are teachers' beliefs about causes of ASD, diagnostic characteristics of children with ASD, and diagnostics activities used to diagnose ASD? Second, what is the level of teachers' general knowledge about autism? Third, what is the knowledge of teachers about evidence-based practices in ASD? Fourth, what is teachers' perceived efficacy about ASD? Fifth, what were the training needs of teachers in order to serve children with ASD? For each research question, differences among pre-, primary, middle, and high school teachers are also investigated. By investigating differences among various teacher groups, it would be possible to determine the specific needs of teachers working in different school settings. This would allow professionals who provide professional development services and programs to teachers know the areas of assistance teachers need in relation to working with children and students with disabilities.

\section{METHODOLOGY}

\section{Participant Recruitment and Procedures}

To recruit participants for the present study, 12 cities were randomly selected from the 12 NUTS 1 (Nomenclature of Territorial Units for Statistics) regions of Turkey. One city was selected from each region. Next, 16 schools ( 4 preschools, 4 primary schools, 4 middle schools, and 4 high schools) were randomly selected from the list of schools in each city, totaling up to 192 school across Turkey. School administrators were contacted by phone to explain the purpose of the study and the right of voluntary participation. Administrators of nine schools across six regions opted out of the study. Therefore, the survey was sent electronically to 4026 teachers in 183 schools. Four hundred seventyeight teachers completed the survey with a return rate of $11.9 \%$. The survey return rate was relatively 
lower in this study in comparison to those of similar studies. However, the present study used random selection to determine study participants as opposed to other studies that used convenient sampling.

Participants included 92 preschools, 105 primary school, 126 middle school, and 155 high school teachers 88 different public schools across 12 different cities in Turkey. Special education teachers were not included in the present study. Of 478 participants, 277 were female and 201 were male. The mean age for participants was 37.3 years $(S D=6.2)$. The highest level of education attained was a bachelor's degree for most participants $(82.6 \%)$; however, some had a master's $(15.1 \%)$ or doctoral degree $(2.3 \%)$. Majority of participants did not have prior experience of interacting with individuals with autism $(84.3 \%)$. Only $4.2 \%$ of participants reported having a family member or friend with ASD and $15.7 \%$ reported having teaching experience with individuals with ASD. With respect to training in ASD, 27.8 reported attending at least one training session focused on ASD (e.g., conference, seminar, in-service training). Table 1 presents participant demographics by school type.

Table 1

Participant demographics by school type (\%)

\begin{tabular}{lrrrrr} 
& $\begin{array}{c}\text { Preschool } \\
(n=92)\end{array}$ & $\begin{array}{r}\text { Primary Sch. } \\
(n=105)\end{array}$ & $\begin{array}{r}\text { Middle Sch. } \\
(n=126)\end{array}$ & $\begin{array}{r}\text { High Sch. } \\
(n=155)\end{array}$ & $\begin{array}{r}\text { Overall } \\
(n=478)\end{array}$ \\
\hline Gender (Female) & 88.1 & 45.7 & 42.9 & 44.5 & 52.7 \\
$\quad$ Education & & & & & \\
Bachelor's & 96.7 & 89.5 & 76.2 & 74.8 & 82.6 \\
$\quad$ Master's & 3.3 & 10.5 & 20.6 & 20.6 & 15.1 \\
$\quad$ Doctorate & 0 & 0 & 3.2 & 4.6 & 2.3 \\
Teaching Experience & & & & & \\
$\quad$ Less than 1 year & 8.7 & 2.9 & 0 & 0 & 2.3 \\
1-5 years & 20.7 & 14.3 & 9.5 & 13.5 & 14 \\
5-10 years & 44.6 & 27.6 & 23.8 & 10.3 & 24.3 \\
10-15 years & 21.7 & 20 & 26.2 & 31.6 & 25.7 \\
$\quad$ More than 15 years & 4.3 & 35.2 & 40.5 & 44.5 & 33.7 \\
Family member/ friend with ASD (Yes) & 2.2 & 5.7 & 6.3 & 2.6 & 4.2 \\
Teaching children with ASD (Yes) & 23.9 & 10.5 & 14.3 & 15.5 & 15.7 \\
Training in ASD (Yes) & 47.8 & 37.1 & 16.7 & 18.7 & 27.8 \\
\hline
\end{tabular}

\section{Instrument}

The survey used in the present study was developed based on previous research in this area (Hansen, 2015; Hartley-McAndrew, Doody, \& Metz, 2014; Mavropoulou \& Padeliadu, 2000; Mitchell \& Locke, 2015; Rakap et al., 2016; Stone, 1987) and consisted of four sections. The first section was designed to gather demographic information about participants. This included information about gender, age, teaching experience (in years), highest level of education obtained, experience with individuals with autism, and training in ASD. The second section was designed to explore teachers' knowledge about causes and diagnosis (criteria and testing) of ASD. In this section, teachers were asked three questions: (1) Which of the following factors do you think are among the main causes of autism? (2) Which of the followings do you think are among the diagnostic criteria of autism? and (3) Which of the following do you think is the main activity used to diagnose autism? In order to determine whether teachers knew the top two possible causes of autism, and the top diagnostic activity used to diagnose children with autism, we limited the number of options teachers could select for the first and third question to 2 and 1. For the second question, teachers were asked to select 7 options among 14 provided as we aimed to determine whether they knew all diagnostic traits of autism described in DSM 5 (APA, 2013). The third section focused on investigating teachers' general knowledge and perceptions of ASD. This section included two main questions. The first question measuring teachers' knowledge of autism included 16 statements and teachers were asked to rate each statement as True or False. The second question investigating teachers' perceptions about autism included 9 statements and teachers were asked to read each statement and rate their response using a 4-point Likert scale. The last section was developed to evaluate teachers' knowledge about effective 
practices for treatment of children with autism as well as their training needs to serve children with autism more effectively. The first question in this section asked teachers to select 5 evidence-based treatments for autism among 44 treatment options provided. The second question asked teachers about the areas in which they need training in order to work with children with autism. Teachers were allowed to select all options if it was appropriate for their individual needs.

The survey was developed in two stages. In the first stage, the research team developed the survey questions based on the previous research. In this state, two methods were used to collect validity evidence. First, a panel of experts (i.e., four faculty member from the field of special education) evaluated the survey to determine whether (a) each section of the survey is measuring what it intended to measure, (b) the survey represents the content with sufficient depth, (c) the questions are appropriate for the study sample, and (d) the survey is compressive enough to collect information needed to address the study questions. Moreover, experts were asked to rate the intelligibility of the questions using yes/no response options. When a no was selected for intelligibility of a question, respondents were also asked their opinions about how to make the question more understandable. Based on the information obtained from the panel, the survey was revised by removing one question and re-wording two questions. Second, the survey was administered to 40 teachers who were not part of the study sample (filed test). Teachers were asked to complete the survey and rate intelligibility of the questions using yes/no response options. When a no was selected for intelligibility of a question, they were asked to provide their opinions about making the question more understandable. Information obtained from the field test was used to revise the survey further.

In the second stage, to collect reliability evidence, the final version of the survey was piloted with 50 teachers. Participants at this stage were asked to respond the survey twice with 10 days' discrepancy between the two administrations to determine test-retest reliability coefficient, an appropriate measure of reliability for knowledge questions. Moreover, for the third section of the survey where teachers' knowledge and perceived efficacy about ASD was measured by yes/no or Likert-type questions, the internal consistency was determined by calculating split-half reliability and Cronbach's alpha coefficients, respectively. Analyses of test-retest reliability indicated high reliability $(r=.94)$ between the two administrations. In addition, split-half reliability and Cronbach's alpha coefficients were .86 and .89 , also indicating high reliability. Teachers who participated in the pilot studies did not participate in the original study.

\section{Data Analysis}

For survey items evaluating teachers' general and more specific knowledge about ASD (e.g., causes, diagnostic traits and diagnostic activities, evidence-based practices) and their training needs, frequencies and percentages were calculated by school type. A chi-square test of independence was performed to examine differences among teachers who work in different school types as it was the appropriate statistical analysis to determine significant relationships between two nominal variables. When a significant difference was observed as a result of chi-square test, pairwise comparisons for proportions are conducted with $\mathrm{R}$ stats package ( $\mathrm{R}$ Core Team, 2016) to determine exact location of the difference. False discovery rate procedure was used to adjust $p$-values for multiple comparisons (Benjamini \& Hochberg, 1995). For items focused on teachers' perceived efficacy about ASD, means and range were reported by school type. 


\section{FINDINGS}

\section{Causes of ASD}

Teachers were asked which 2 of 9 causes listed they believed were the primary causes of ASD. Overall, teachers believed genetic $(45.2 \%)$ and neurological factors $(40.6 \%)$ were the two primary causes of ASD, with environmental exposures a distant fifth (17.8\%). Considerable amounts of teachers selected mental illness $(28.2 \%)$ and vaccinations $(25.6 \%)$ as main causes of ASD. Factors such as malnutrition in pregnancy, parenting, dietary/nutritional issues, and drug use of mothers during pregnancy were believed to be one of the primary causes of autism by less than $20 \%$ of teacher sample.

Table 2

Percentage of teachers endorsing each option for cause, diagnostic traits, diagnostic activities by school type

\begin{tabular}{|c|c|c|c|c|c|c|}
\hline & $\begin{array}{c}\text { Preschool } \\
(n=92)\end{array}$ & $\begin{array}{c}\text { Primary S. } \\
(n=105)\end{array}$ & $\begin{array}{c}\text { Middle S. } \\
(n=126)\end{array}$ & $\begin{array}{l}\text { High S. } \\
(n=155)\end{array}$ & $\begin{array}{c}\text { Overall } \\
(n=478)\end{array}$ & $p$-value \\
\hline \multicolumn{7}{|l|}{ Cause } \\
\hline Genetic & 56.6 & 67.6 & 27 & 38 & 45.2 & $<0.001$ \\
\hline Neurological & 44.6 & 22.8 & 48.4 & 43.8 & 40.6 & $<0.001$ \\
\hline Mental illness & 19.6 & 24.8 & 32.6 & 32.2 & 28.2 & \\
\hline Vaccinations & 10.8 & 26.6 & 30.2 & 29.6 & 25.6 & 0.004 \\
\hline Environmental exposure & 22.8 & 21 & 14.2 & 15.4 & 17.8 & \\
\hline Malnutrition in pregnancy & 17.4 & 9.6 & 17.4 & 22 & 17.2 & \\
\hline Parenting & 18.4 & 10.4 & 16.6 & 7 & 12.6 & 0.023 \\
\hline Dietary/nutritional issues & 3.2 & 8.6 & 8.8 & 11 & 8.4 & \\
\hline Drug use of mother & 6.6 & 8.6 & 4.8 & 0.6 & 4.6 & 0.018 \\
\hline \multicolumn{7}{|l|}{ Diagnostic criteria } \\
\hline \multicolumn{7}{|l|}{ Diagnostic traits } \\
\hline Poor back-and-forth communication skills & 73.9 & 58.1 & 48.4 & 49.7 & 55.9 & 0.001 \\
\hline Hyper- or hypo-reactivity to sensory input & 63 & 61 & 42.1 & 58.1 & 55.4 & 0.005 \\
\hline Poor nonverbal communicative behaviors & 82.6 & 61.9 & 41.3 & 45.8 & 55.2 & $<0.001$ \\
\hline Repeating same behavior over and over & 42.4 & 42.9 & 54 & 60.6 & 51.5 & 0.009 \\
\hline Intense restricted interests & 56.5 & 39 & 46.8 & 52.3 & 48.7 & \\
\hline Inability make/sustain friendships & 63 & 62.9 & 40.5 & 32.9 & 47.3 & $<0.001$ \\
\hline Strong resistance to change in routines & 43.5 & 52.4 & 29.4 & 43.2 & 41.6 & 0.004 \\
\hline \multicolumn{7}{|l|}{ Non-diagnostic traits } \\
\hline Consistent disruptive/aggressive behavior & 71.7 & 74.3 & 83.3 & 76.1 & 76.8 & \\
\hline Having severe temper tantrums & 59.8 & 70.5 & 73 & 85.2 & 73.8 & $<0.001$ \\
\hline Inability to focus on tasks & 47.8 & 54.3 & 63.5 & 79.4 & 63.6 & $<0.001$ \\
\hline Fidgeting and squirming constantly & 39.1 & 55.2 & 56.3 & 31 & 44.6 & $<0.001$ \\
\hline Illogical thinking & 21.7 & 39 & 44.4 & 41.3 & 37.9 & 0.004 \\
\hline Inability to control unwanted thoughts & 19.6 & 20 & 61.9 & 22.6 & 31.8 & $<0.001$ \\
\hline Seeing/hearing things that do not exist & 15.2 & 8.6 & 15.1 & 21.9 & 15.9 & 0.036 \\
\hline \multicolumn{7}{|l|}{ Diagnostic activities } \\
\hline $\begin{array}{l}\text { Psychological, educational, or developmental } \\
\text { testing }\end{array}$ & 47.8 & 46.7 & 39.7 & 40.6 & 43.1 & \\
\hline Behavior observation & 21.7 & 10.5 & 27.8 & 22.6 & 21.1 & 0.013 \\
\hline Genetic testing & 15.2 & 21.9 & 15.9 & 21.9 & 19 & \\
\hline Medical/physical examination & 8.7 & 5.7 & 8.7 & 8.4 & 7.9 & \\
\hline Family interview & 5.4 & 9.5 & 5.6 & 5.8 & 6.5 & \\
\hline Blood test & 1.1 & 5.7 & 2.4 & 0.6 & 2.3 & \\
\hline
\end{tabular}

Participants selected 2 options for cause of ASD, 7 options for diagnostic criteria, and 1 option for diagnostic activities; therefore, the sum of each column in each section is $200 \%, 700 \%$, and $100 \%$, respectively. Diagnostic traits were developed based on DSM 5 (APA, 2013).

Top three causes selected were genetic (57\%), neurological $(45 \%)$, and environmental exposures (23\%) for preschool teachers; genetic (68\%), vaccinations (27\%), and mental illness (25\%) for primary school teachers; neurological (48\%), mental illness (33\%), and vaccinations (30\%) for middle 
school teachers; and neurological (44\%), genetic (38\%), and mental illness (32\%) for high school teachers. Table 2 presents teacher responses with respect to main causes of ASD by school type.

\section{Diagnostic traits of ASD}

Teachers were asked which 7 of 14 traits listed they believed were most diagnostic traits of ASD. Of the 14 traits, 7 were diagnostic indicators of ASD while the other 7 were not. As seen in Table 2, three non-diagnostic traits, consistent disruptive/aggressive behaviors (77\%), severe temper tantrums (74\%), and inability to focus on tasks (64\%), were believed to be the top three diagnostic indicators of ASD. Of seven diagnostic traits, four were endorsed by the majority of teachers (i.e., poor back-and-forth communication skills [56\%], hyper- or hypo-reactivity to sensory input [55\%], poor nonverbal communicative behaviors [55\%], and repeating same behavior over and over [52\%]). The least commonly endorsed diagnostic trait was strong resistance to change in routines (42\%). From seven non-diagnostic traits, three listed above were endorsed by the majority of teachers as indicators of autism. The least commonly endorsed non-diagnostic trait was seeing/hearing things that do not exist $(15 \%)$.

Majority of preschool and primary school teachers endorsed 5 of 7 diagnostic traits of autism while only 3 and 1 were endorsed by high school and middle school teachers, respectively. With respect to seven non-diagnostic traits, majority of preschool teachers selected two traits as diagnostic indicators of autism, while primary school teachers selected four traits, middle school teachers selected five traits, and high school teachers selected three traits as diagnostic indicators of ASD.

\section{Diagnostic activities for ASD}

Teachers were asked to choose 1 among 6 diagnostic activities they believed was used to diagnose ASD. As shown in Table 2, approximately half of participating teachers (43\%) selected psychological, educational, or developmental testing, followed by behavior observations $(21 \%)$ and genetic testing (19\%). The least commonly selected diagnostic activities were blood test (2\%), family interview (7\%), and medical/physical examination (8\%). Across teacher groups, psychological, educational, or developmental testing was the top choice (range $=40 \%$ for middle school teachers $-48 \%$ for preschool teachers), while blood test was the least selected choice (range $=$ less than $1 \%$ for high school teachers $-6 \%$ for primary school teachers).

\section{General knowledge of ASD}

To evaluate teachers' general knowledge of ASD, 16 questions with true/false response options were asked. Many questions were answered correctly by the majority of participating teachers. For example, majority of teachers knew that ASD is more common in boys than girls $(80 \%)$, children with ASD has atypical play patterns $(74 \%)$, ASD does not affect children only $(82 \%)$ or is not fatal over time (88\%), ASD is a developmental disorder $(69 \%)$ and not curable (77\%), changing a child's diet would not lessen the severity of ASD (58\%), and children with siblings who have ASD are at a higher risk of developing the disorder (63\%). Majority of teachers also knew that teachers could not give a preliminary diagnosis of ASD when they believed a child had autism (88\%). On the other hand, some misconceptions about ASD and characteristics of children who have the disorder. For example, majority of teachers believed that symptoms of ASD remain stable throughout the individual's life (83\%), all individuals with ASD have low IQs (52\%), conditions during pregnancy cause autism (65\%), eating habits of most children with ASD are typical (60\%), and ASD cannot be diagnoses earlier than 24 months (72\%). Moreover, approximately half of the participating teachers taught that many individuals with ASD are clumsy and uncoordinated and ASD occurs more commonly among higher socioeconomic and education levels. Table 3 presents teachers' general knowledge of ASD by school type. 
Table 3

Percentage of teachers responding "true" to general knowledge of ASD questions by school type

\begin{tabular}{|c|c|c|c|c|c|c|}
\hline Items & $\begin{array}{l}\text { Preschool } \\
(n=92)\end{array}$ & $\begin{array}{l}\text { Primary S. } \\
(n=105)\end{array}$ & $\begin{array}{l}\text { Middle S. } \\
(n=126)\end{array}$ & $\begin{array}{l}\text { High S. } \\
(n=155)\end{array}$ & $\begin{array}{l}\text { Overall } \\
(n=478)\end{array}$ & $\begin{array}{l}p- \\
\text { value }\end{array}$ \\
\hline $\begin{array}{l}\text { After being diagnosed, symptoms of ASD remain } \\
\text { stable throughout the individual's life }\end{array}$ & 77.2 & 83.8 & 82.5 & 85.2 & 82.6 & \\
\hline All individuals with ASD have low IQs & 45.7 & 61 & 48.4 & 52.3 & 51.9 & \\
\hline ASD is more common in boys than girls & 88 & 73.3 & 79.4 & 80.6 & 80.1 & \\
\hline ASD only affects children & 12 & 22.9 & 16.7 & 19.4 & 18 & \\
\hline ASD can be fatal over time & 9.8 & 17.1 & 9.5 & 10.3 & 11.5 & \\
\hline Children with ASD have typical patterns of play & 6.5 & 30.5 & 24.6 & 34.8 & 25.7 & $<0.001$ \\
\hline $\begin{array}{l}\text { Children with siblings who have ASD are at a } \\
\text { higher risk of developing the disorder }\end{array}$ & 80.4 & 67.6 & 68.3 & 43.9 & 62.6 & $<0.001$ \\
\hline Conditions during pregnancy may cause autism & 85.9 & 77.1 & 53.2 & 53.5 & 64.9 & $<0.001$ \\
\hline $\begin{array}{l}\text { If a teacher believes a student has ASD, he or she } \\
\text { can give a preliminary diagnosis }\end{array}$ & 5.4 & 17.1 & 9.5 & 14.8 & 12.1 & 0.047 \\
\hline $\begin{array}{l}\text { Many individuals with ASD are clumsy and } \\
\text { uncoordinated }\end{array}$ & 43.5 & 49.5 & 48.4 & 54.8 & 49.8 & \\
\hline ASD is a developmental disorder & 78.3 & 62.9 & 62.7 & 71.6 & 68.6 & 0.042 \\
\hline ASD is curable & 22.8 & 15.2 & 25.4 & 26.5 & 23 & \\
\hline $\begin{array}{l}\text { Eating habits of most children with ASD are } \\
\text { typical }\end{array}$ & 50 & 45.7 & 73.8 & 65.2 & 60.3 & $<0.001$ \\
\hline Changing a child's diet lessens severity of ASD & 35.9 & 45.7 & 40.5 & 43.2 & 41.6 & \\
\hline $\begin{array}{l}\text { ASD occurs more commonly among higher } \\
\text { socioeconomic and educational levels }\end{array}$ & 25 & 48.6 & 54.8 & 55.5 & 47.9 & $<0.001$ \\
\hline Autism cannot be diagnosed earlier than 24 months & 55.4 & 74.3 & 78.6 & 73.5 & 71.5 & 0.002 \\
\hline
\end{tabular}

\section{Appropriate treatments for ASD}

Among the 24 treatment methods listed, teachers were asked to select 5 treatments they believed to be effective for individuals with ASD. As shown in Table 4, the most commonly endorsed established treatments were behavioral interventions (64\%), comprehensive behavioral treatment $(42 \%)$, and language training $(41 \%)$. Among eight emerging treatments, functional communication training (41\%), developmental relationship-based treatment (33\%), and picture exchange communication system (17.4\%) were the most commonly endorsed treatments. From the list of unestablished treatments, facilitated communication (30\%), gluten/case-in free diet (23\%), and social behavioral learning strategy $(22 \%)$ were the top three treatments endorsed by teachers. The least endorsed treatments were peer training $(15 \%)$ and pivotal response training $(8 \%)$ for established treatments, music therapy (5\%) and sign instruction (4\%) for emerging treatments, and movement-based intervention (10\%) and shock therapy $(0 \%)$ for unestablished treatments. Table 4 shows percentage of teachers endorsing each option as an appropriate treatment for ASD by school type.

Table 4

Percentage of teachers endorsing each option as an appropriate treatment for ASD by school type

\begin{tabular}{|c|c|c|c|c|c|c|}
\hline & $\begin{array}{c}\text { Preschool } \\
(n=92)\end{array}$ & $\begin{array}{c}\text { Primary S. } \\
(n=105)\end{array}$ & $\begin{array}{c}\text { Middle S. } \\
(n=126)\end{array}$ & $\begin{array}{l}\text { High S. } \\
(n=155)\end{array}$ & $\begin{array}{c}\text { Overall } \\
(n=478)\end{array}$ & $p$-value \\
\hline \multicolumn{7}{|l|}{ Established Interventions } \\
\hline Behavioral interventions & 70.7 & 77.1 & 46 & 65.2 & 63.8 & $<0.001$ \\
\hline Comprehensive behavioral treatment & 47.8 & 16.2 & 63.5 & 38.7 & 42.1 & $<0.001$ \\
\hline Language training & 31.5 & 23.8 & 43.7 & 54.8 & 40.6 & $<0.001$ \\
\hline Social skills training & 42.4 & 19 & 58.7 & 35.5 & 39.3 & $<0.001$ \\
\hline Parent training & 20.7 & 32.4 & 19 & 26.5 & 24.7 & \\
\hline Naturalistic teaching & 17.4 & 37.1 & 17.5 & 7.1 & 18.4 & $<0.001$ \\
\hline Peer training & 4.3 & 1 & 14.3 & 31 & 14.9 & $<0.001$ \\
\hline Pivotal response training & 1.1 & 0 & 14.3 & 11 & 7.5 & $<0.001$ \\
\hline \multicolumn{7}{|l|}{ Emerging Interventions } \\
\hline Functional communication training & 44.6 & 61 & 38.9 & 28.4 & 41.4 & $<0.001$ \\
\hline Developmental relationship-based treatment & 27.2 & 37.1 & 34.9 & 32.9 & 33.3 & \\
\hline Picture exchange communication system & 15.2 & 32.4 & 24.6 & 2.6 & 17.4 & $<0.001$ \\
\hline Exercise & 12.0 & 5.7 & 16.7 & 11.6 & 11.7 & \\
\hline Imitation-based intervention & 19.6 & 9.5 & 4 & 0 & 6.9 & $<0.001$ \\
\hline Massage therapy & 0 & 7.6 & 4.8 & 7.7 & 5.4 & 0.047 \\
\hline
\end{tabular}


Music therapy

Sign instruction

Unestablished Interventions

Facilitated communication

Gluten/Case-in-free diet

Social behavioral learning strategy

Sensory intervention

Auditory integration training

Concept mapping

Movement-based intervention

Shock therapy

Participants were asked to select 5 treatment options for ASD. Therefore, the sum of each column in each section is $500 \%$.

Practices were categorized based on the report of the National Autism Center (2015).

\section{Perceived efficacy about ASD}

Overall, teachers reported that they are knowledgeable about ASD indicated by a mean score of 2.9/4. Mean scores for five of eight remaining statements were also higher than 2, indicating that teachers perceived themselves to be knowledgeable about symptoms $(M=2.8)$, causes $(M=2.5)$, diagnosis $(M$ $=2.5)$, and prevalence $(M=2.5)$ of ASD. Moreover, teachers reported that they would know if they met a person with $\operatorname{ASD}(M=2.6)$. However, participating teachers also reported that they do not know what happens to individuals with ASD as they age $(M=3.0)$; they are not aware of treatment options for children with $\operatorname{ASD}(M=3.2)$; and they cannot meet the needs of students with $\operatorname{ASD}(M=3.4)$. Table 5 illustrates teachers' perceptions about ASD by school type.

Table 5

Mean scores and score ranges for teachers' perceived efficacy about ASD by school type

\begin{tabular}{|c|c|c|c|c|c|}
\hline Statement & $\begin{array}{l}\text { Preschool } \\
(n=92)\end{array}$ & $\begin{array}{l}\text { Primary S. } \\
(n=105)\end{array}$ & $\begin{array}{l}\text { Middle S. } \\
(n=126)\end{array}$ & $\begin{array}{l}\text { High S. } \\
(n=155)\end{array}$ & $\begin{array}{l}\text { Overall } \\
(n=478)\end{array}$ \\
\hline I am knowledgeable about ASD & $3.4(2-4)$ & $2.9(1-4)$ & $2.9(1-4)$ & $2.7(1-4)$ & $2.9(1-4)$ \\
\hline I understand how ASD is diagnosed & $2.5(1-4)$ & $2.6(1-4)$ & $2.6(1-4)$ & $2.5(1-4)$ & $2.5(1-4)$ \\
\hline I know what kind of symptoms individuals with ASD have & $2.8(1-4)$ & $2.6(1-4)$ & $3.0(1-4)$ & $2.8(1-4)$ & $2.8(1-4)$ \\
\hline I know what happens to people with ASD as they age & $2.1(1-4)$ & $2.2(1-3)$ & $2.0(1-4)$ & $1.8(1-3)$ & $2.0(1-4)$ \\
\hline I am knowledgeable about what causes ASD & $2.5(1-4)$ & $2.5(2-4)$ & $2.2(1-4)$ & $2.7(2-4)$ & $2.5(1-4)$ \\
\hline I am aware of treatment options for children with ASD & $1.8(1-3)$ & $1.5(1-3)$ & $2.0(1-3)$ & $1.8(1-3)$ & $1.8(1-3)$ \\
\hline I understand how common ASD is in the general population & $2.3(1-4)$ & $2.5(1-4)$ & $2.7(2-4)$ & $2.4(1-4)$ & $2.5(1-4)$ \\
\hline I believe I would know if I met a person/student with ASD & $3.1(2-4)$ & $2.4(1-4)$ & $2.7(2-4)$ & $2.5(2-4)$ & $2.6(1-4)$ \\
\hline I believe I can meet the needs of students with ASD & $1.5(1-3)$ & $1.4(1-3)$ & $1.8(1-4)$ & $1.7(1-3)$ & $1.6(1-4)$ \\
\hline
\end{tabular}

Response options were Strongly Disagree (1), Disagree (2), Agree (3), Strongly Agree (4). Mean scores are presented above.

\section{Training needs of teachers about ASD}

As shown in Table 6, the majority of teachers reported their needs for training in three areas listed: behavior management and positive behavior support (74.1\%), evidence-based instructional strategies for children with ASD (54\%), and characteristics and nature of ASD (53.6\%). Little less than half of the participating teachers reported training needs on identification, assessment, and diagnosis of ASD (47.3\%) and interventions for communication and social developments (46.7\%). Table 6 shows teachers' training needs by school type.

Table 6

Percentage of teachers selecting each training area by school type

\begin{tabular}{|c|c|c|c|c|c|c|}
\hline & $\begin{array}{c}\text { Preschool } \\
(n=92)\end{array}$ & $\begin{array}{c}\text { Primary S. } \\
(n=105)\end{array}$ & $\begin{array}{c}\text { Middle } S . \\
(n=126)\end{array}$ & $\begin{array}{l}\text { High S. } \\
(n=155)\end{array}$ & $\begin{array}{l}\text { Overall } \\
(n=478)\end{array}$ & $p$-value \\
\hline \multicolumn{7}{|l|}{ I would benefit from further training on: } \\
\hline Characteristics and nature of ASD & 65.2 & 53.3 & 47.6 & 51.6 & 53.6 & \\
\hline Identification, assessment, and diagnosis of ASD & 59.8 & 57.1 & 26.2 & 50.3 & 47.3 & $<0.001$ \\
\hline $\begin{array}{l}\text { Evidence-based instructional strategies for children } \\
\text { with ASD }\end{array}$ & 76.1 & 38.1 & 54.8 & 50.9 & 54.0 & $<0.001$ \\
\hline $\begin{array}{l}\text { Interventions for communication and social } \\
\text { development }\end{array}$ & 51.1 & 47.6 & 52.3 & 38.7 & 46.7 & \\
\hline Behavior management and positive behavior support & 94.6 & 80.0 & 49.2 & 78.1 & 74.1 & $<0.001$ \\
\hline
\end{tabular}




\section{DISCUSSION and CONCLUSION}

Previous studies have shown that teachers' knowledge and perceptions play an important role on the education of children with ASD (Finke, Finke, McNaughton, \& Drager, 2009; Vakil, Welton, O'Connor, \& Kline, 2009). With the increase in the prevalence of ASD, it is more likely to have children who are diagnosed with ASD or who show symptoms of ASD educated in inclusive classroom settings in public schools. This requires general education teachers to have increased, most recent and evidence-based knowledge about ASD. This study is among the initial studies investigating Turkish general education teachers' knowledge and perceptions about ASD. Specifically, the present study investigated teachers' (a) knowledge about causes, diagnostic traits and activities of ASD, (b) general knowledge and perceived efficacy about ASD, (c) knowledge about evidence-based practices in ASD, and (d) training needs in relation to ASD. Overall, Turkish teachers' knowledge and perceptions about ASD appear to be relatively poor. However, differences among teachers who work in different schools are observed. Below findings are discussed in detail.

The first question aimed to investigate teachers' knowledge about the causes, diagnostic traits and activities of ASD. Findings of the present study with respect to causes of ASD suggest poor knowledge among Turkish teachers. Several international studies also reported low levels of teacher knowledge regarding causes of ASD (e.g., Al-Sharbati et al., 2015; Arif et al., 2013; Mavropoulou \& Padeliadu, 2000). Although exact causes of ASD are not known, current research evidence suggests that genetics, neurological and environmental factors play important roles in the genesis of autism (Autism Society of America, 2015). Although teachers selected genetic and neurological factors as the top two causes of ASD, factors such as mental illness, vaccinations, malnutrition, and parenting styles were selected by many teachers as the primary causes. Compared to other teachers, preschool are more likely to select genetic, neurological factors, and environmental exposure as primary causes of ASD and less likely to report mental illness, vaccinations, and nutritional issues as the primary causes. This is somewhat encouraging as preschool teachers are among the professionals who are likely to have the initial contact with children with disabilities.

With respect to diagnostic criteria and activities, majority of preschool and primary school teachers endorsed at least 5 of 7 diagnostic traits correctly and psychological, educational or developmental testing was selected as the top strategy used to diagnose ASD by roughly half of these teachers. While not sufficient, this finding is promising as there is no universal referral system to identify children with ASD in Turkey and it is often a responsibility of professionals who have the initial contact with young children (such as pre- or primary school teacher) to refer suspected children for a comprehensive evaluation (Rakap et al., 2016). However, it should also be noted that the majority of teachers across school types selected aggressive behaviors, temper tantrums, and inability to focus on tasks as diagnostic traits of ASD. This finding aligns with the findings of previous research reporting confusion and uncertainty about the diagnostic traits and characteristics of children with ASD among teachers or other professionals (e.g., Heidgerken et al., 2005; Imran et al., 2011; Mitchell \& Locke, 2015) and is somewhat concerning because some children could be mislabeled by their teachers as having ASD while they actually do not have it or have some other impairments.

The second question sought to examine teachers' general knowledge about ASD. Previous research has shown that many professionals including teachers have many misconceptions about ASD (AlSharbati et al., 2015; Arif et al., 2013; Hartley-McAndrew, Doody, \& Mertz, 2014; Heidgerken, Geffken, Modi, \& Frakey, 2005; Helps, Newsom-Davis, \& Callias, 1999). Some of these incorrect beliefs might affect the way teachers interact with or teach to children with ASD. For example, over $80 \%$ of the teachers in the present study reported symptoms of ASD remain stable over time and more than half of the teacher believed that all children with ASD have low IQs. A teacher with these beliefs might give up on children with ASD by thinking that no matter what she/he does, it would not be beneficial for children with ASD. Also, a teacher who believes that conditions during pregnancy cause 
autism may misinform parents seeking information about the genesis of autism and lead them to feel guilty about their child's condition.

The next question focused on teachers' knowledge about evidence-based interventions in ASD. Many teachers who participated in the study endorsed practices determined to be established or emerging by the National Autism Center (2015) as evidence -based (e.g., behavioral interventions, language training, social skills training, and functional communication training). While these correct endorsements are encouraging, many teachers also selected several unestablished interventions (e.g., facilitated communication, gluten/case-in free diet) as evidence-based. Moreover, practices such as naturalistic teaching that are mainly implemented in inclusive settings by general education teachers were endorsed by relatively small proportion of teachers. Although many teachers may not be directly responsible for using these practices to teach children with ASD, having correct and up-to-date knowledge about them is important in informing parents about practices that work for children with ASD.

The fourth question aimed to explore perceived efficacy of teachers about ASD. On average, teachers perceived themselves to be knowledgeable about ASD and reported that they know symptoms and causes of ASD and how it is diagnosed. These findings contradict with the findings with respect to teachers' knowledge about causes, symptoms, and diagnosis of ASD reported earlier. This means that what teachers believe to be correct about causes, symptoms, and diagnosis of ASD may actually be incorrect. This warrants further the need for teacher training on ASD.

Aim of the last question was to investigate training needs of teachers in relation to ASD. Although preschool teachers appeared to have somewhat better knowledge about ASD in comparison to other teachers, they were more willing to participate in training programs focused on all aspects of ASD. Preschool teachers' level of knowledge and willingness to learn new information about ASD is encouraging as early diagnosis and treatment plays a key role in the development and learning of children with ASD (Koegel, Koegel, Ashbaugh, \& Bradshaw, 2014). A very large proportion of teachers reported their willingness to attend training for behavior management and positive behavior support to meet the needs of children with ASD. Teachers' request for training in behavior management aligns with their endorsements of non-diagnostic traits such as consistent and aggressive behaviors and severe temper tantrums as diagnostic traits.

\section{Limitations}

There are at least five limitations of this study readers must be aware of while interpreting the findings. First, although reaching a nationally representative sample was aimed, a relatively small number of teachers (when compared to actual number of general education teachers in Turkey) agreed to participate in the present study, which might have affected generalizability of study findings. Second, special education teachers were not included in the sample because the aim of the study was to investigate knowledge and perceptions of general education teachers. However, data collected from special education teachers could have been used as criterion. Third, an online survey was used to collect data for the present study. Although with the developments in technology, web-based surveys are increasingly used to collect data in recent years, it is possible for respondents to falsify their demographic information and use the internet to obtain information about the questions asked in the survey, which, in turn, undermines the reliability and accuracy of the results and the validity of conclusions drawn from the findings (Braunsberger, Wybenga, \& Gates, 2007; Lefever, Dal, \& Matthíasdóttir, 2007). Moreover, online surveys might have low response rate and high coverage error (i.e., the difference between defined target population and who actually responded to the survey; Couper, 2000).

Another limitation was related to the way survey questions were asked. Teachers were given a list options to choose for the majority of questions which allow them to guess when they did not know the answer. It could have been better if they were asked to list, for example, diagnostic traits, causes, or 
evidence-based practices. The last limitation was related to determining error with respect to nonrespondents (Lindner, Murphy, \& Briers, 2001). Teachers choosing to participate in the study might have better knowledge and perceptions about ASD and those who did not want to participate in the present study are simply not be interested in autism and therefore, have less knowledge about ASD and related issues addressed in the study.

\section{Future Directions: Implications for Teacher Training and Research}

Most obvious implication of the findings of this study with respect to teacher training is the need for professional development programs to increase teachers' awareness and knowledge in various topics and issues related to ASD. Attempt to equip teachers with the most current and evidence-based knowledge should begin while they are in pre-service teacher training programs by enriching teacher education curriculum with special education courses and continue with in-service training programs focused on ASD. Probst and Leppert (2008) suggest that information about characteristics of children and students with ASD and intervention approaches to support development and learning of these children should be integrated into the teacher training curricula. Without a well-organized effort to train teachers and other professionals, the concerns with respect to teacher qualifications and shortage of professionals who are specialized in ASD will continue.

In Turkey, general and special education teacher preparation programs are separated from each other and faculty and students in each group (except a small number of students who qualify for double majors in a general education area and special education) have little or no opportunities to interact and cooperate. As a long-term solution to teacher preparation, at minimum, preschool and primary school teacher preparation programs should be unified with special education teacher preparations programs, so that teacher candidates take courses and obtain practical experiences to work with children both with and without disabilities. The unified teacher preparation aligns with the current education policy to include more children with disabilities in general education programs and curricula. However, until this major change to how general and special education teachers are prepared in Turkey is made, general education teacher preparation programs should include more focus on special education. Currently, many teacher education programs only offer an introductory special education course in which ASD and related topics are discussed and taught for several weeks. This course may be adequate to raise general awareness about disabilities and inclusion, but it is definitely not sufficient to increase specific knowledge and awareness about ASD among teacher candidates from different programs (Rakap et al., 2016). General education teacher preparation programs should provide preservice teachers with opportunities to gain knowledge and skills about main characteristics of children with ASD including causes and diagnostic traits, early intervention and evidence-based instructional practices, cooperative program planning, social skills interventions, and transition planning (Eren \& Brucker, 2011).

For professional development efforts to be effective, development of knowledge and skills began during in-service training must be sustained during in-service teaching (Sindelar, Brownell, \& Billingsley, 2010). Therefore, continued professional development opportunities should also be provided to teachers and other professional who work with children with ASD in the field. A major barrier to the development and implementation of pre- and in-service training programs for teachers and other professionals who work with children with ASD faced in Turkey and other countries around the world is the scarcity of higher education personal specialized in ASD (Rakap et al., 2016). As a result, many teacher preparation programs across the nation are not able to offer courses on autism not only to general education pre-service teachers but also special education pre-service teachers. To overcome this barrier and reach teachers who are not close to the universities or other organizations offering ongoing professional development on ASD, web-based professional development or certification programs can be designed by the ASD experts. Studies investigating effects of web-based professional development programs in helping teachers develop and improve their competencies, 
knowledge, and skills about ASD report encouraging findings (Rakap, Jones, \& Emery, 2015). Thus, a professional development program developed by autism experts and approved by the Ministry of National Education can be valuable resource for pre- and in-service teachers who work with children with ASD and want to increase their knowledge and skills about autism.

Future research should replicate the findings of the present study with a larger sample of teachers using additional research methods (e.g., qualitative) and tools (e.g., interviews or observations). Future research efforts should also focus on developing web-based professional development or certification programs on autism and investigating their effects on practices of teachers who work with children with ASD.

Over the last two decades, the number of children diagnosed with ASD has dramatically increased. As a result, more children and students with ASD participate in general education (Syriopoulou-Dell et al., 2012). Teachers' knowledge and perceptions about ASD is found to be a critical component for the diagnosis and education of children with ASD (Mesibov, Shea, \& Schopler, 2004). Findings of the current study showed that Turkish general education teachers who participated in the current study are not appropriately trained to work with children with ASD. The lack of adequate training in the area of ASD warrants the development of professional development or certification programs to train inservice teachers and other professionals to support development and learning of children with ASD.

\section{REFERENCES}

Al-Sharbati, M. M., Al-Farsi, Y. M., Ouhtit, A., Waly, M. I., Al-Shafaee, M., Al-Farsi, O., ... \& Al-Adawi, S. (2013). Awareness about autism among school teachers in Oman: A cross-sectional study. Autism, 19(1), 6-13.

American Psychiatric Association. (1994). Diagnostic and statistical manual (4th ed.). Washington, DC: APA Press.

American Psychiatric Association. (2013). Diagnostic and statistical manual of mental disorders (5th ed.). Washington, DC: American Psychiatric Association.

Arif, M. M., Niazy, A., Hassan, B., \& Ahmed, F. (2013). Awareness of autism in primary school teachers. Autism Research and Treatment, 1-5.

Autism Society of America. (2015). Causes. Retrieved from: http://www.autism-society.org/what-is/causes/ on October 3, 2018.

Autism Society of America. (2016). Diagnosis. Retrieved from: http://www.autism-society.org/whatis/diagnosis/ on October 3, 2018.

Baio, J. (2014). Prevalence of autism spectrum disorder among children aged 8 years - autism and developmental disabilities monitoring network, 11 sites, United States, 2010. MMWR Surveillance Summaries, 63(3), 1-21. Retrieved from: http://www.cdc.gov/mmwr/pdf/ss/ss6302.pdf on October 3, 2018.

Benjamini, Y., \& Hochberg, Y. (1995). Controlling the false discovery rate: a practical and powerful approach to multiple testing. Journal of the Royal Statistical Society. Series B (Methodological), 57(1), 289-300.

Braunsberger, K., Wybenga, H., \& Gates, R. (2007). A comparison of reliability between telephone and webbased surveys. Journal of Business Research, 60(7), 758-764.

Cakiroglu, O., \& Melekoglu, M. A. (2014). Statistical trends and developments within inclusive education in Turkey. International Journal of Inclusive Education, 18(8), 798-808.

Cascella, P. W., \& Colella, C. S. (2004). Knowledge of autism spectrum disorders among Connecticut school speech-language pathologists. Focus on Autism and Other Developmental Disabilities, 19(4), 245-252.

Elsabbagh, M., Divan, G., Koh, Y. J., Kim, Y. S., Kauchali, S., Marcín, C., ... \& Yasamy, M. T. (2012). Global prevalence of autism and other pervasive developmental disorders. Autism Research, 5(3), 160-179.

Eren, R. B., \& Brucker, P. O. (2011). Practicing evidence-based practices. In B. Reichow, P. Doehring, D. V. Cicchetti, \& F. R. Volkmar (Eds.), Evidence-based practices and treatments for children with autism (pp. 309-341). New York, NY: Springer.

Finke, E. H., Finke, E. H., McNaughton, D. B., \& Drager, K. D. (2009). “All children can and should have the 
opportunity to learn": General education teachers' perspectives on including children with autism spectrum disorder who require AAC. Augmentative and Alternative Communication, 25(2), 110-122.

Guthrie, W., Swineford, L. B., Nottke, C., \& Wetherby, A. M. (2013). Early diagnosis of autism spectrum disorder: stability and change in clinical diagnosis and symptom presentation. Journal of Child Psychology and Psychiatry, 54(5), 582-590.

Hart, J. E., \& More, C. M. (2013). Investigating the impact of technology on pre-service teacher knowledge of autism spectrum disorder. Education and Training in Autism and Developmental Disabilities, 48(4) 504513.

Hartley-McAndrew, M., Doody, K. R., \& Mertz, J. (2014). Knowledge of autism spectrum disorders in potential first-contact professionals. North American Journal of Medicine and Science, 7(3), 97-102.

Heidgerken, A. D., Geffken, G., Modi, A., \& Frakey, L. (2005). A survey of autism knowledge in a health care setting. Journal of Autism and Developmental Disorders, 35(3), 323-330.

Helps, S., Newsom-Davis, I. C., \& Callias, M. (1999). Autism: The teacher's view. Autism, 3(3), 287-298.

Imran, N., Chaudry, M. R., Azeem, M. W., Bhatti, M. R., Choudhary, Z. I., \& Cheema, M. A. (2011). A survey of autism knowledge and attitudes among the healthcare professionals in Lahore, Pakistan. BMC Pediatrics, 11(1), 107-113.

James, L. W., Pizur-Barnekow, K. A., \& Schefkind, S. (2014). Online survey examining practitioners' perceived preparedness in the early identification of autism. American Journal of Occupational Therapy, 68(1), 1320.

Khanna, R., \& Jariwala, K. (2012). Awareness and knowledge of autism among pharmacists. Research in Social and Administrative Pharmacy, 8(5), 464-471.

Kim, Y. S., Leventhal, B. L., Koh, Y. J., Fombonne, E., Laska, E., Lim, E. C., ... \& Song, D. H. (2011). Prevalence of autism spectrum disorders in a total population sample. American Journal of Psychiatry, 168(9), 904-912.

Koegel, R. L., \& Koegel, L. K. E. (1995). Teaching children with autism: Strategies for initiating positive interactions and improving learning opportunities. Baltimore, MD: Paul H Brookes Publishing.

Koegel, L. K., Koegel, R. L., Ashbaugh, K., \& Bradshaw, J. (2014). The importance of early identification and intervention for children with or at risk for autism spectrum disorders. International Journal of SpeechLanguage Pathology,16(1), 50-56.

Lane, K. L., Carter, E. W., Common, E., \& Jordan, A. (2012). Teacher expectations for student performance: Lessons learned and implications for research and practice. Classroom Behavior, Contexts, and Interventions, 25, 95-129.

Lefever, S., Dal, M., \& Matthiasdottir, A. (2007). Online data collection in academic research: advantages and limitations. British Journal of Educational Technology, 38(4), 574-582.

Lindner, J. R., Murphy, T. H., \& Briers, G. E. (2001). Handling nonresponse in social science research. Journal of Agricultural Education, 42(4), 43-53.

Mavropoulou, S., \& Padeliadu, S. (2000). Greek teachers' perceptions of autism and implications for educational practice: A preliminary analysis. Autism, 4(2), 173-183.

Mesibov, G. B., Shea, V., \& Shopler, E. (2004). The TEACCH approach to autism spectrum disorders. New York, NY: Plenum Press.

Mitchell, G. E., \& Locke, K. D. (2015). Lay beliefs about autism spectrum disorder among the general public and childcare providers. Autism, 19(5), 553-561.

National Autism Center. (2015). Findings and conclusions: National standards project, phase 2. Randolph, MA.

Ozcelik, A. A., Soysal, S., Arhan, E., Demir, E., Gucuyener, K., \& Serdaroglu, A. (2015). Autism spectrum disorder management practices and level of knowledge among general pediatricians. Gazi Medical Journal, 26(4), 158-162.

Park, M., Chitiyo, M., \& Choi, Y. S. (2010). Examining pre-service teachers' attitudes towards children with autism in the USA. Journal of Research in Special Educational Needs, 10(2), 107-114.

Probst, P., \& Leppert, T. (2008). Brief report: Outcomes of a teacher training program for autism spectrum disorders. Journal of Autism and Developmental Disorders, 38(9), 1791-1796.

Rakap, S. (Ed.). (2017). Türkiye'de otizm spektrum bozukluğu ve özel ĕgitim [Autism spectrum disorder and special education in Turkey]. Istanbul: Tohum Autism Foundation.

Rakap, S., Balikci, S., Parlak-Rakap, A., \& Kalkan, S. (2016). An analysis of Turkish pre-service teachers' knowledge of autism spectrum disorder. SAGE Open, 6(3), 1-11.

Rakap, S., Jones, H. A., \& Emery, A. K. (2015). Evaluation of a web-based professional development program (Project ACE) for teachers of children with autism spectrum disorders. Teacher Education and Special Education, 38(3), 221-239.

Reichow, B., Hume, K., Barton, E. E., \& Boyd, B. A. (2018). Early intensive behavioral intervention (EIBI) for young children with autism spectrum disorders (ASD). Cochrane Database of Systematic Reviews, 5, CD009260-CD009260. 
Schwartz, H., \& Drager, K. D. (2008). Training and knowledge in autism among speech-language pathologists: A survey. Language, Speech, and Hearing Services in Schools, 39(1), 66-77.

Shah, K. (2001). What do medical students know about autism? Autism, 5(2), 127-133.

Shaw, E., \& Hatton, D. (Eds.). (2009). Screening and early identification of autism spectrum disorders (Queries: An Occasional Paper Compiling States' Approaches to Current Topics). Chapel Hill: FPG Child Development Institute, National Early Childhood Technical Assistance Center, The University of North Carolina.

Sindelar, P. T., Brownell, M. T., \& Billingsley, B. (2010). Special education teacher education research: Current status and future directions. Teacher Education and Special Education, 33(1), 8-24.

Stone, W. L. (1987). Cross-disciplinary perspectives on autism. Journal of Pediatric Psychology, 12(4), 615630.

Syriopoulou-Delli, C. K., Cassimos, D. C., Tripsianis, G. I., \& Polychronopoulou, S. A. (2012). Teachers' perceptions regarding the management of children with autism spectrum disorders. Journal of Autism and Developmental Disorders, 42(5), 755-768.

Team, R. C. (2016). R: A language and environment for statistical computing [Computer software]. Vienna: R Foundation for Statistical Computing.

Tipton, L. A., \& Blacher, J. (2014). Brief report: Autism awareness: Views from a campus community. Journal of Autism and Developmental Disorders, 44(2), 477-483.

Vakil, S., Welton, E., O’Connor, B., \& Kline, L. S. (2009). Inclusion means everyone! The role of the early childhood educator when including young children with autism in the classroom. Early Childhood Education Journal, 36(4), 321.

Volkmar, F. R., Rogers, S., Paul, R., \& Pelphrey, K.A. (2014). Handbook of autism and pervasive developmental disorders (4th ed.). Hoboken, NJ: John Wiley \& Sons, Inc.

Yasar, P., \& Cronin, K. A. (2014). Perspectives of college of education students in Turkey on autism spectrum disorders. International Journal of Special Education, 29(1), 61-75.

Yumak, N., \& Akgul, E. M. (2010). Investigating elementary school administrators' and teachers' perceptions on children with autism. Procedia-Social and Behavioral Sciences, 2(2), 910-914. 


\section{TÜRKÇE GENIŞLETILMIŞ ÖZET}

Otizm spektrum bozukluğu (OSB), belirtileri erken çocukluk döneminde ortaya çıkan, genellikle etkilerini ömür boyu sürdüren, bireylerin sosyal etkileşim ve iletişim kurma becerilerini olumsuz yönde etkileyen, sınırlı ilgi ve tekrarlanan davranışlara neden olan nöro-gelişimsel bir bozukluktur (American Psychiatric Association, 2013). Son y1llarda tüm dünyada OSB tanıs1 alan bireylerin sayısında önemli bir artış görülmeye başlamıştır (Arif vd., 2013; Elsabbagh vd., 2012; Kim vd., 2011). Ülkemizde otizmli bireylerin sayısını belirlemeye yönelik ulusal bir tarama sistemi bulunmamasına rağmen tüm dünyadaki artışa paralel olarak ülkemizde de otizmli bireylerin sayısında artış olduğu düşünülmektedir (Rakap, 2017). Bu bağlamda, eğitimini resmi özel eğitim okullarında ya da kaynaştırma sınıflarında alan otizmli çocuk sayısı günden güne artmaktadır (Rakap, 2017). Resmi okullarda eğitimsel ve gelişimsel destek alan otizmli çocukların sayısının artmasıyla birlikte otizmli çocuklarla çalışan ya da çalışma olasılığı olan öğretmenlerin otizm ve otizmli çocukların eğitimi hakkında bilgi sahibi olması önem kazanmaktadır (Koegel \& Koegel, 1995; Lane, Carter, Common, \& Jordan, 2012).

Uluslararası alanyazında, otizmli çocuklar ile çalışan uzmanların otizm hakkındaki görüşlerini inceleyen çalışmaların 1980'li yıllardan beri yürüttüldüğü görülmektedir (örn., Stone, 1987). Ulusal alanyazında ise benzer çalışmalara 2010 yılı ve sonrasında rastlanmaktadır (Ozcelik vd., 2015; Rakap vd., 2016; Yasar \& Kronin, 2014; Yumak \& Akgul, 2010). Bu bağlamda yürütülen dört çalışmanın üçünde, çocuk doktorlarının ya da öğretmen adaylarının otizmle ilgili bilgi düzeyleri incelenirken sadece bir çalışmada (Yumak \& Akgul, 2010) okul yöneticileri ve ilkokul öğretmelerin bilgi düzeyleri ve tutumları incelenmiştir. Yumak ve Akgul (2010), ilkokul öğretmenlerinin otizm hakkında çok sınırlı bilgiye ve eğitime sahip olduklarını ve dolayısıyla otizmli çocuklarla nasıl çalışacaklarını bilmediklerini rapor etmiştir.

$\mathrm{Bu}$ çalışma, genel eğitim öğretmenlerin otizm hakkındaki genel bilgi ve bakış açılarını incelemek, otizmde bilimsel dayanaklı uygulamalarla ilgili bilgi düzeylerini belirlemek ve otizmli çocuklarla çalışmak için mesleki gelişim ihtiyaçlarını belirlemek amacıyla tasarlanmıştır. Çalışma kapsamında, anaokulu, ilkokul, ortaokul ve lise kademelerinde görev yapan öğretmenler arasında ilgili değişkeler bağlamında farlılıklar da incelenmiştir. Çalışmaya, 12 farklı ilde yer alan 88 okulda görev yapan 92 okulöncesi, 105 ilkokul, 126 ortaokul ve 155 lise öğretmeni katılmıştır.

Çalışma kapsamında araştırma ekibi tarafından öğretmenlerin otizm ve ilişkili konular hakkında bilgi düzeylerini belirlemek amacıyla uluslararası alanyazında kullanılan ölçekler temel alınarak bir ölçek geliştirilmiş, ölçek hakkında özel eğitim alanında görev yapan dört akademisyenden uzman görüşü alınmış ve ölçeğin psikometrik özellikleri incelenmiştir. Ölçek dört kısımdan oluşmaktadır. Birinci kısımda öğretmenlerle ilgili demografik bilgiler, ikinci kısımda öğretmenlerin otizmin nedenleri ve tanılanmasıyla ilgili bilgi düzeyleri, üçüncü kısımda öğretmenlerin otizmle ilgili genel bilgileri ve dördüncü kısımda öğretmenlerin otizmde bilimsel dayanaklı uygulamalarla ilgili bilgi düzeyleri ve eğitim ihtiyaçları hakkında veri toplanması amaçlanmıştır. Ölçeğin test-tekrar test güvenirliği $r=.94$ olarak belirlenmiştir. $\mathrm{R}$ istatistik paketi kullanılarak ortalama, sıklık ve yüzde analizi yapıldıktan sonra ki-kare testi ile farklı eğitim kademesinde görev yapan öğretmenlerin bilgi düzeyleri arasındaki faklar incelenmiştir.

Otizmin nedenleri bağlamında bulgular, öğretmenlerin \%40'ından fazlasının genetik ve nörolojik nedenleri otizme neden olan temel faktörler olarak belirlediğini göstermektedir. Okulöncesi sınıflarında görev yapan öğretmenlerin \%57'si genetik ve \%45'ide nörolojik faktörlerin otizme neden olduğunu belirtirken diğer kademelerde çalışan birçok öğretmenin akıl hastalıklarının ve aşıların otizme neden olduğuna dair inanışlarının olduğunu görülmektedir. Tanılayıcı kriterler bağlamında, otizmli çocuklarda sıklıkla görülen fakat tanılama kriterlerinden olmayan yıkıcı ve zarar verici 
davranışlar (\%77), ağır düzeyde sinir krizleri (\%74) ve odaklanamama (\%64) davranışları en çok seçilen davranışladır. Bulgular, okulöncesi ve ilkokul öğretmenlerinin büyük çoğunluğunun 7 tanılama kriterinden 5'ini doğru bildiğini göstermektedir. Öğretmenlerin otizmle ilgili genel bilgi düzeylerine bakıldığında, katılımcıların büyük çoğunluğunun sorulan sorulara doğru cevap verdiği görülmektedir (Örneğin, otizmin erkeklerde daha yaygın olarak görülmesi [\%80], otizmli çocukların atipik oyun örüntüsüne sahip olmaları [\%74] ve otizmin ölümcül olmamas1 [\%88]). Ancak, öğretmenlerin otizmle ilgili bazı yanlış bilgilere de sahip olduğu görülmektedir (Örneğin, otizmin belirtilerinin ömür boyu aynı kalması [\%83], hamilelik sırasındaki koşulların otizme neden olması [\%65], otizmli tüm bireylerin düşük zeka puanına sahip olması [\%52]). Otizmde bilimsel dayanaklı uygulamalar ile ilgili bilgi düzeyleri incelendiğinde, öğretmenlerin \%64ünün etkililiği araştırmalar tarafından kanıtlanan davranışsal müdahaleleri seçtiği, ancak yardımlı iletişim (\%30) ve gluten/kasein diyeti (\%23) gibi etkisiz müdahalelerin de birçok öğretmen tarafindan bilimsel dayanaklı uygulama olarak seçildiği görülmektedir.

Yukarıda belirtilen bulgulara karşın birç̧ok öğretmenin kendisini otizm hakkında bilgili gördüğü bulunmuştur $(M=2.94 / 4)$. Daha açık belirtmek gerekirse, öğretmenlerin kendilerini otizmin semptomları $(M=2.8)$, nedenleri $(M=2.5)$, tanılanması $(M=2.5)$ ve yaygınlığ $(M=2.5)$ hakkında bilgi sahibi olarak gördükleri bulunmuştur. Aynı zamanda öğretmenler, otizmli bireylere yaşları ilerledikçe ne olduğunu bilmediklerini $(M=3.0)$; otizmli bireyler için var olan müdahale tekniklerini bilmediklerini $(M=3.2)$ ve otizmli öğrencilerin ihtiyaçlarını karşılayamayacaklarını $(M=3.4)$ belirtmişlerdir. Öğretmenlerin büyük çoğunluğu davranış yönetimi ve olumlu davranış desteği (\%74.1), bilimsel dayanaklı uygulamalar (\%54), otizmin doğası (\%53.6) ile otizmin değerlendirilmesi ve tanılanması (\%47.3) konularında mesleki gelişime ve eğitime ihtiyaç duyduklarını belirtmiş̧lerdir.

Çalışmanın bulguları, genel olarak öğretmenlerin otizm hakkındaki bilgi ve algılarının düşük olduğunu, ancak farklı kademelerde çalışan öğretmenlerin bilgi düzeyleri arasında farklılıklar bulunduğunu ortaya koymuştur. Örneğin, okulöncesi öğretmenlerinin otizmin nedenleri ve tanılayıc1 kriterleri, sınıf öğretmenleri ise sadece otizmin tanılayıcı kriterleri konusunda diğer kademelerde çalışan öğretmenlere kıyasla daha bilgili olduğu bulunmuştur. Ayrıca çalışmanın bulguları, farklı kademelerden öğretmenlerin otizm ve bilimsel dayanaklı uygulamalar ile ilgili yanlış bilgilere ve inanışlara sahip olduğunu ortaya koymuştur. Dahası, öğretmenlerin otizm hakkında sahip olduklarını düşündükleri bilgiler ile gerçek bilgi düzeyleri arasında da farklar olduğu bulunmuştur. Çalışmaya katılan öğretmenlerin büyük çoğunluğu otizm ve otizmli çocukların eğitimi konusunda mesleki gelişime ihtiyaç duyduklarını belirtmişlerdir. Çalışma sonucunda elde edilen bulgular doğrultusunda, öğretmenlerin otizm ve otizmli çocuklar ile çalışma konularında bilgi ve beceri düzeylerini artıracak mesleki gelişim ve eğitim programlarının geliştirilmesine olan ihtiyaç açık bir şekilde görülmektedir. 